\title{
TGF- $\beta 1$ mediates the effects of aspirin on colonic tumor cell proliferation and apoptosis
}

\author{
YUYI WANG ${ }^{1}, \mathrm{CHI} \mathrm{DU}^{1,2}$, NAN ZHANG $^{1}$, MEI LI $^{1}$, YANYANG LIU ${ }^{1}$, \\ MAOYUAN ZHAO ${ }^{1}$, FENG WANG ${ }^{1}$ and FENG LUO ${ }^{1}$ \\ ${ }^{1}$ Department of Medical Oncology, Lung Cancer Center and State Key Laboratory of Biotherapy, \\ West China Hospital of Sichuan University, Chengdu, Sichuan 610041; ${ }^{2}$ Department of Oncology, \\ The Second People's Hospital of Neijiang, Neijiang, Sichuan 641000, P.R. China
}

Received October 15, 2015; Accepted March 23, 2017

DOI: $10.3892 / \mathrm{ol} .2018 .8047$

\begin{abstract}
Previous studies have demonstrated that aspirin serves an important role in chemoprevention and the suppression of colorectal cancer (CRC); however, the underlying mechanisms for this inhibition by aspirin remain unclear. Aspirin is capable of promoting apoptosis through prostaglandin-dependent orprostaglandin-independent signaling pathways. In the prostaglandin-dependent pathways, inhibition of cyclooxygenase (COX), particularly COX-2, is the primary mechanism known to be involved in aspirin-induced CRC suppression. Previous studies have implicated prostaglandin-independent signaling pathways and certain associated proteins, including SOX7, in aspirin-induced CRC suppression. In the present study, a newly-characterized association between aspirin, transforming growth factor (TGF)- $\beta 1$ and CRC inhibition was identified. Specifically, aspirin triggers $\mathrm{CRC}$ cell apoptosis by inducing the secretion of TGF- $\beta 1$, and the increased TGF- $\beta 1$ then leads to apoptosis and proliferation inhibition in CRC cells.
\end{abstract}

\section{Introduction}

Aspirin, also known as acetylsalicylic acid, is a >100-year-old drug widely used due to its analgesic, antipyretic and anti-inflammatory properties (1). Aspirin is capable of inhibiting the cyclooxygenase (COX) activity of the enzyme prostaglandin $\mathrm{G} / \mathrm{H}$-synthase and blocking the biosynthesis of prostaglandins (2). The recognition that oral administration of aspirin may reduce the risk of certain types of cancer makes

Correspondence to: Professor Feng Luo or Professor Feng Wang, Department of Medical Oncology, Lung Cancer Center and State Key Laboratory of Biotherapy, West China Hospital of Sichuan University, 37 Guoxue Alley, Chengdu, Sichuan 610041, P.R. China

E-mail: luofeng@medmail.com.cn

E-mail: wangfeng5024@126.com

Key words: aspirin, transforming growth factor- $\beta 1$, colonic cancer, apoptosis, growth inhibition aspirin a promising candidate for tumor therapy. The high tumor-suppressive efficacy of aspirin treatment observed in colorectal cancer (CRC) has increased the number of studies investigating aspirin-induced CRC suppression.

The pathogenesis of CRC is closely associated with local inflammation in the intestine. Various inflammatory cells or cytokines are responsible for the carcinogenesis of colorectal cells (3). Among them, prostaglandin is well-known for its long history of promoting survival, proliferation and invasion in cancer cells (4). Therefore, the suppression of the production of prostaglandin by inhibiting the activity of COX-2 with non-steroidal anti-inflammatory drugs (NSAIDs) such as aspirin becomes a promising choice for CRC suppression. Compared with other types of malignant tumors, CRC is relatively sensitive to aspirin treatment, as revealed by several independent clinical trials (5-7). A number of studies have also demonstrated that COX-2 inhibition is an important strategy for the chemopreventive treatment of colon-associated disorders (8-11), resulting in a lower risk of cancer. The inhibition of COX-2-dependent signaling pathways is one mechanism involved in the good tumor-suppressive efficacy of aspirin. COX-2-independent pathways are also of importance; high concentrations of aspirin may induce apoptosis via 15-lipoxygenase-1 in human HT-29 colonic carcinoma cells (12). Sex-determining region Y-box 7 (SOX7) is upregulated by aspirin and is involved in the aspirin-mediated growth inhibition of human SW480 colonic cancer cells (13). The regulation of SOX7 by aspirin is implemented through the p38/MAPK cascade (13). Although a number of novel associations have been identified, the mechanism underlying the inhibition of $\mathrm{CRC}$ by aspirin remains unclear.

Transforming growth factor- $\beta 1$ (TGF- $\beta 1$ ) is a versatile cytokine involved in cell growth, differentiation and immune modulation (14-16). TGF- $\beta 1$ is a member of the TGF- $\beta$ superfamily and regulates proliferation and apoptosis in epithelial, endothelial, neuronal and hematopoietic cells (17). TGF- $\beta 1$ is also capable of inducing apoptosis in a number of malignant tumor cells, contributing to tumor suppression (18). In the present study, the associations between aspirin, TGF- $\beta 1$ expression and CRC inhibitionwere examined, and a novel aspect of how aspirin increases CRC inhibition and apoptosis was identified. 


\section{Materials and methods}

Cell culture and treatment. The CT26 mouse coloncarcinoma cell line was obtained from the American Type Culture Collection (Manassas, VA, USA) and maintained at $37^{\circ} \mathrm{C}$ in a humidified condition of $95 \%$ air and $5 \% \mathrm{CO}_{2}$. Cells were cultured in $75-\mathrm{cm}^{2}$ flasks or 6-well plates with RPMI-1640 medium (Thermo Fisher Scientific, Inc., Waltham, MA, USA) supplemented with $10 \%$ heat-inactivated fetal bovine serum (FBS; Gibco; Thermo Fisher Scientific, Inc.), $100 \mathrm{U} / \mathrm{ml}$ penicillin and $100 \mathrm{U} / \mathrm{ml}$ streptomycin. Prior to the addition of aspirin (Sigma-Aldrich; Merck KGaA, Darmstadt, Germany) or LY364947 (Sigma-Aldrich; Merck $\mathrm{KGaA}$ ), which is an inhibitor of TGF- $\beta$ receptor (R)-I, cells were allowed to adhere to 6- or 96-well plates for $24 \mathrm{~h}$. For the TGF- $\beta 1$ treatment experiment, two groups were used: i) $100 \mathrm{ng} / \mathrm{ml}$ TGF- $\beta 1$ (BioLegend, Inc., San Diego, CA, USA); ii) an equal amount of PBS for the control group. For the aspirin treatment group, cells were divided into three groups: i) $3.5 \mu \mathrm{M}$ aspirin; ii) combination of $3.5 \mu \mathrm{M}$ aspirin and $1 \mu \mathrm{MLY} 364947$ (LY364947 was added and after $2 \mathrm{~h}$ the culture medium was replaced with an equal volume of RPMI-1640 medium containing $3.5 \mu \mathrm{M}$ aspirin); iii) an equal amount of dimethyl sulfoxide (DMSO) as the control group. Each group was treated for 24, 36 and $48 \mathrm{~h}$ prior to harvesting for additional study.

Cell viability assay. Cell viability was assessed using a MTT Cell Proliferation and Cytotoxicity Assaykit (Beyotime Institute of Biotechnology, Haimen, China). Cells $\left(1 \times 10^{4}\right)$ were seeded on 96-well plates and cultured for 24,36 and $48 \mathrm{~h}$, followed by the addition of MTT solution to the cells for $4 \mathrm{~h}$. Subsequent to the removal of the medium, the remaining MTT formazan crystals were solubilized in DMSO and analyzed at $560 \mathrm{~nm}$ using a microplate reader (Benchmark Electronics, Inc., Angleton, TX, USA).

ELISA. CT26 tumor cells were collected and then homogenized in radioimmunoprecipitation assay buffer $(0.1 \%$ SDS, $0.5 \%$ deoxycholate, $1 \%$ Triton $\mathrm{X}-100,150 \mathrm{mM} \mathrm{NaCl}$ and $50 \mathrm{mM}$ Tris- $\mathrm{HCl}$ ), followed by centrifugation at $17,000 \mathrm{x} \mathrm{g}$ for $30 \mathrm{~min}$ at $4^{\circ} \mathrm{C}$. Adiethylaminobenzaldehyde assay was used to determine the protein concentration of the samples. The prepared samples were stored at $-80^{\circ} \mathrm{C}$ until used. The levels of TGF- $\beta 1$ in each sample were assessed using mouse ELISA kits (R\&D Systems, Inc., Minneapolis, MN, USA), according to the manufacturer's protocol, and the colorimetric reaction was measured at $450 \mathrm{~nm}$ using a microplate reader (Benchmark Electronics, Inc.).

Flow cytometry analysis of apoptosis. CT26 cells were treated, as aforementioned, then harvested and washed in cold PBS prior to staining using an Apoptosis Detection kit (BD Biosciences, San Jose, CA, USA), according to the manufacturer's protocol. Briefly, cells were resuspended to a concentration of $1 \times 10^{5}$ cells/sample and double-stained with fluorescein isothiocyanate-conjugated Annexin V and propidium iodide. The samples were analyzed by flow cytometry, as previously described (19) (FACSAria ${ }^{\mathrm{TM}}$ SORP; BD Biosciences, Erembodegem, Belgium).
Western blot analysis. The cells were harvested, lysed and the total protein was quantified using a Micro Bicinchoninic Protein Assay kit (Pierce; Thermo Fisher Scientific, Inc.) according to the protocol of the manufacturer. Total protein $(10 \mu \mathrm{g})$ from each sample was separated by electrophoresis using 12\% SDS-PAGE, transferred onto poly vinylidene fluoride membranes, pre-blocked with 5\% skim milk (MerckKGaA) for $90 \mathrm{~min}$ at room temperature and then incubated using the primary antibodies $(1: 1,000)$, including mouse-anti- $\beta$-actin (cat. no., MAB8929), rabbit-anti-B-celllymphoma2 (Bcl-2; cat. no., AF810), rabbit-anti-Bcl-2-associated X protein (Bax; cat. no., AF820), rabbit-anti-Caspase3 (cat. no., AF-605-NA; R\&D Systems, Inc.), rabbit-anti-Caspase8 (cat. no., 9429; Cell Signaling Technology, Inc., Danvers, MA, USA) overnight at $4^{\circ} \mathrm{C}$. The corresponding secondary antibodies [anti-mouse $\operatorname{Ig}(\mathrm{H}+\mathrm{L})$; cat. no., 0216], [anti-rabbit $\operatorname{Ig}(\mathrm{H}+\mathrm{L})$ cat. no., A0208; dilution, 1:10,000; Beyotime Institute of Biotechnology, Haimen, China] were applied for $1 \mathrm{~h}$ at room temperature $\beta$-catenin was used as a loading control. Signals were developed on X-ray films following exposure to electrochemiluminescence advanced luminescence and Image-Pro Plus 6.0 (Media Cybernetics, Inc., Rockville, MD, USA) was used to test the iodine value of the blots.

Statistical analysis. Data are expressed as the mean \pm standard deviation. Statistical analyses were performed using SPSS (version 16.0; SPSS Inc., Chicago, IL, USA). Inter-group statistical significance was determined using a Student's unpaired t-test. $\mathrm{P}<0.05$ was considered to indicate a statistically significant difference. ${ }^{*} \mathrm{P}<0.05,{ }^{* *} \mathrm{P}<0.03,{ }^{* * *} \mathrm{P}<0.01,{ }^{* * * *} \mathrm{P}<0.001$.

\section{Results}

Aspirin induces the secretion of TGF- $\beta 1$ by CT26 cells. The levelsof TGF- $\beta 1$ present in the supernatant fluid of CT26 cells seeded in 6-well plates were determined using an ELISA following aspirin treatment, and the amount of secreted TGF- $\beta 1$ by a certain number of CT26 cells was calculated: Firstly, the amount of secreted TGF- $\beta 1$ in $1 \times 10^{5}$ CT26 cells was tested in each case. Secondly, the number of cells was counted. Then, the average amount of TGF- $\beta 1$ secreted by $1 \times 10^{5} \mathrm{CT} 26$ cells in each case was calculated using the following formula: Total amount of TGF- $\beta 1$ in each case/the number of CT26 cells in this case) $\times 10^{5}$. The results demonstrated that the levels of TGF- $\beta 1$ vary based on the duration of treatment. Treatment with aspirin significantly increased TGF- $\beta 1$ secretion compared with the control $(\mathrm{P}=0.0159$ and $\mathrm{P}=0.0203$ at 36 and $48 \mathrm{~h}$, respectively; Fig. 1). Treatment of CT26 cells with aspirin for longer time points resulted in increased TGF- $\beta 1$ secretion. While, one problem should be noted. The secretion of TGF- $\beta 1$ by CT26 cells is a continuous process and the present study calculated the number of cells following collection of the supernatant fluid of the CT26 cells. The number of cells in control group increased subsequent to culturing for 24,36 or $48 \mathrm{~h}$, as cellular proliferation had continued, while in the aspirin treatment group, the number of cells increased by a small level, or even decrease, as aspirin inhibits growth of cells (20). Despite this, a statistically significant increase in secreted TGF- $\beta 1$ in aspirin group was observed. 
TGF- $\beta 1$

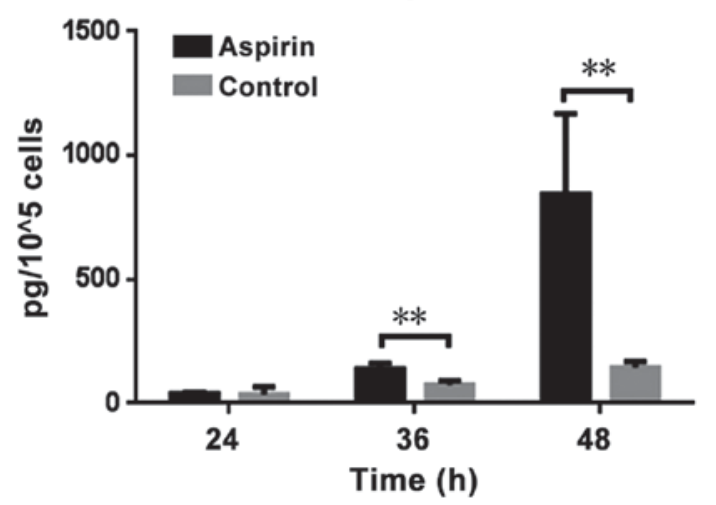

Figure 1 . CT26 cells secrete significantly increased levels of TGF- $\beta 1$ following treatment with aspirin. ELISA was used to determine the levels of TGF- $\beta 1$ in the supernatant fluid of CT26 cells following treatment with $3.5 \mu \mathrm{M}$ aspirin for 24,36 and $48 \mathrm{~h}$. ${ }^{* *} \mathrm{P}<0.03$. TGF- $\beta 1$, transforming growth factor b1.

TGF- $\beta 1$ induces the apoptosis of CT26 cells. An MTT assay demonstrated that TGF- $\beta 1$ significantly decreases the viability of CT26 cells $(\mathrm{P}<0.05$; Fig. $2 \mathrm{~A})$, and induces early and late apoptosis (Fig. 2B and C). Apoptosis serves a key role in cellular development and is a stage-dependent process, including early, intermediate and late-stage apoptotic events. Cells may remain viable if stimulation by aspirin is stopped during early apoptotic events, whereas for late apoptosis defragmentation of DNA is typically observed and this will lead to cell death even if stimulation is halted.

TGF- $\beta 1$ mediates the effects of aspirin on the viability of CT26 cells. In the present study, an MTT assay was used to examine the effect of aspirin on CT26 cells. The concentration of aspirin used was based on results from a previous study from our group (Wang et al, unpublished). A concentration $>10 \mu \mathrm{M}$ was excessive, while no apoptosis or proliferation of CT26 cells was observed when $<3 \mu \mathrm{M}$ aspirin was used(data not shown). Data from the present study demonstrated that treatment with 3 and $3.5 \mu \mathrm{M}$ aspirin led to a significant decrease in cell viability following 24,48 and $72 \mathrm{~h}$ of treatment compared with the control group $(\mathrm{P}<0.03, \mathrm{P}<0.03$ and $\mathrm{P}<0.01$, respectively; Fig. 3A). However, co-treatment witha TGF- $\beta$ R1 inhibitor, LY364947, resulted in a significant increase incell viability following 48 and $72 \mathrm{~h}$ of treatment compared with cells treated with aspirin alone $(\mathrm{P}<0.05)$, suggesting that the inhibition caused by aspirin was mediated by TGF- $\beta 1$. In addition, co-treatment with aspirin and LY364947 significantly decreased the percentage of early and late apoptotic events stimulated by aspirin treatment alone following treatment for $36 \mathrm{~h}$ (late apoptotic events) and $48 \mathrm{~h}$ (early and late apoptotic events) ( $\mathrm{P}<0.05$; Fig. 3B).

The expression of a number of apoptosis-associated proteins was analyzed by western blot analysis following treatment with $3.5 \mu \mathrm{M}$ aspirin and/or $1 \mu \mathrm{M} \mathrm{LY364947.} \mathrm{Changes}$ in the expression of caspase 8 P43, caspase 8 P18, caspase $3, \mathrm{Bcl}-2$ and Bax following treatment with aspirin (data not shown) were significantly rescued when cells were co-treated with aspirin and LY364947 at 24, 36 and $48 \mathrm{~h}$ following treatment (Fig. 3C).

\section{Discussion}

In the present study, it was demonstrated that aspirin induced the secretion of TGF- $\beta 1$ by CT 26 cells, and that TGF- $\beta 1$ in turn led to a decrease in viability and increase in the apoptotic rate CT26 cells. To the best of our knowledge, this is a novel mechanism by which aspirin affects CRC suppression. TGF- $\beta 1$ is one of the mediators of aspirin-induced apoptosis and, through TGF- $\beta 1$, aspirin treatment resulted in the downregulation of certain proteins known to be involved in apoptosis, including Bcl-2, caspase 3 and caspase 8 fragments. It has previously been implicated that the downregulation of Bcl-2 family members $(21,22)$, upregulation of the pro-apoptotic factor Bax (23) and the activation of caspase proteases (24) are involved in TGF- $\beta 1$-induced apoptosis. Bcl-2 and Bax are well known for their roles in apoptosis. Apoptotic caspase proteases are classified into initiators and effectors, according to their point of entry into the apoptotic cascade. Initiator caspases, such as caspase- 8 , are the first to be activated in a particular cell-death pathway, and they activate effector caspases, such as caspase-3, via the cleavage of linker segments $(25,26)$. Once activated, caspases cleave a variety of important structural proteins, enzymes and regulatory molecules (27), which leads to DNA fragmentation (28-30) and subsequentcell apoptosis. The present study also demonstrated an increase in the levels of caspase-8. Aspirin suppresses tumor cell growth indirectly by inducing the secretion of TGF- $\beta 1$. This is similar to the results of a previous study that suggested that ethanol exposure increased TGF- $\beta 1$ signaling through the suppression of Bcl-2 and retinoblastoma proteins, which may have led to apoptotic cell death, including $\beta$-endorphin neurons in the arcuate nucleus of the hypothalamus (31).

Previously, aspirin has attracted attention due to its potential benefit in the chemoprevention of CRC (32). Several clinical studies also reported that aspirin may prolong the overall survival of patients with CRC as a fore mentioned (5-7). A systematic review concluded that the regular use of aspirin reduced the risk of CRC and the 20-year risk of mortality due to CRC (33). Another study which combined the analyses of four randomized trials designed for the primary or secondary prevention of cardiovascular events, identified that the use of aspirin at dosages of $\geq 75 \mathrm{mg}$ daily was associated with a $24 \%$ reduction in incidence and a $35 \%$ reduction in mortality from colon cancer (34). However, the molecular mechanisms by which aspirin inhibits CRC formation and growth have remained unclear; therefore, the utilization of aspirin in CRC therapy remains a disputed issue.

The best known molecular target of aspirin is COX. Aspirin, but not other NSAIDs, may cause irreversible inactivation of COX isozymes through the acetylation of a specific serine moiety (35); yet there is evidence that, in COX negative SW480 colonic cancer cells, aspirin is also able to inhibit the growth of the cells (36). Another study also identified that aspirin may act through COX-independent mechanisms that result in an increased expression of DNA mismatch repair proteins and the subsequent apoptosis in SW480 cells (37). COX-dependent and COX-independent pathways used by aspirin may work cooperatively. For example, it has been suggested that aspirin may sensitize tumor cells to tumor 

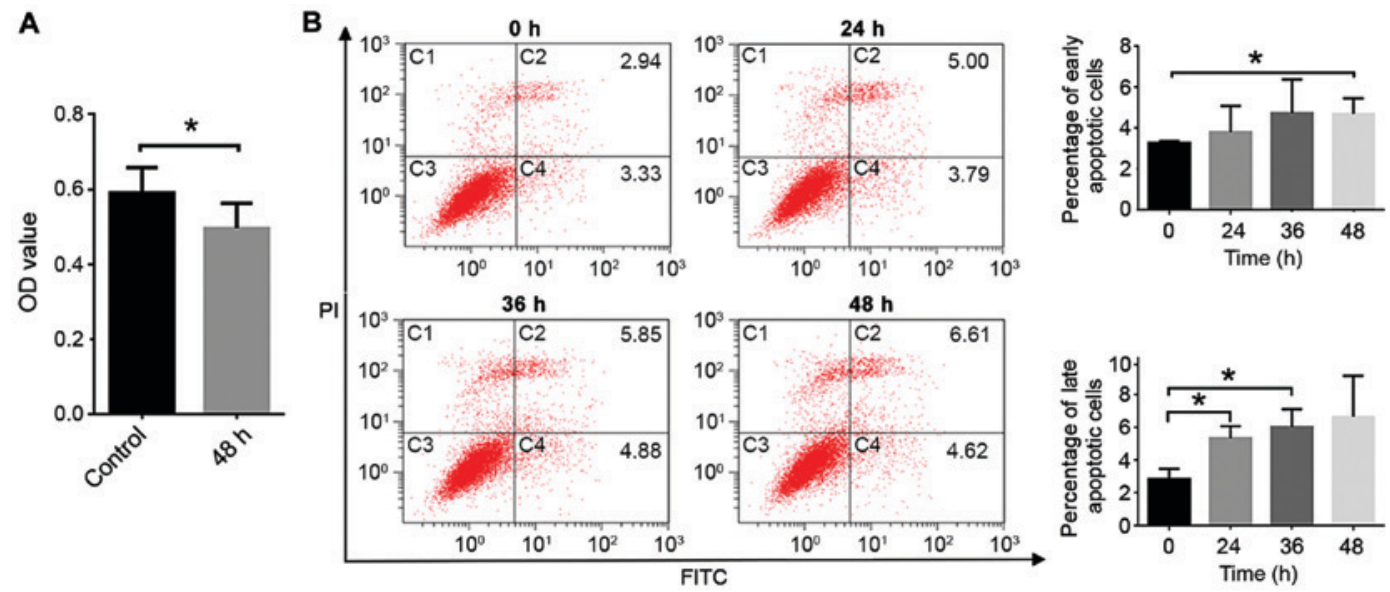

Figure 2. TGF- $\beta 1$ promotes apoptosis of CT26 cells. (A) MTT assay and (B) flow cytometry results following treatment of CT26 cells with $100 \mathrm{ng} / \mathrm{ml}$ TGF- $\beta 1$ for the indicated time points. "P<0.05. TGF- $\beta 1$, transforming growth factor $\mathrm{b} 1$; OD, optical density; FITC, fluorescein isothiocyanate; PI, propidium iodide.

A

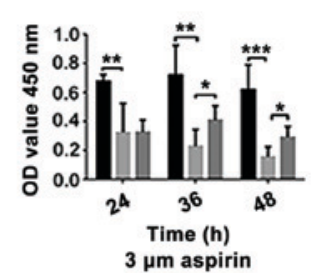

B

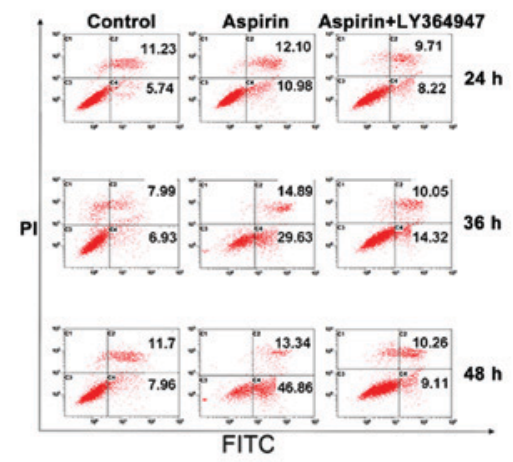

Eontrol Aspirin
Aspirin+LY364947
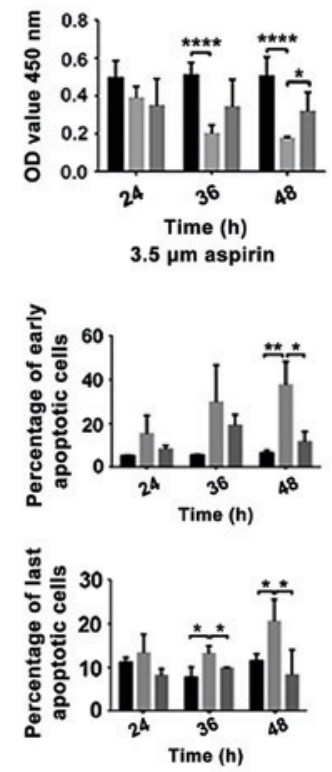

Control

Aspirin+LY364947
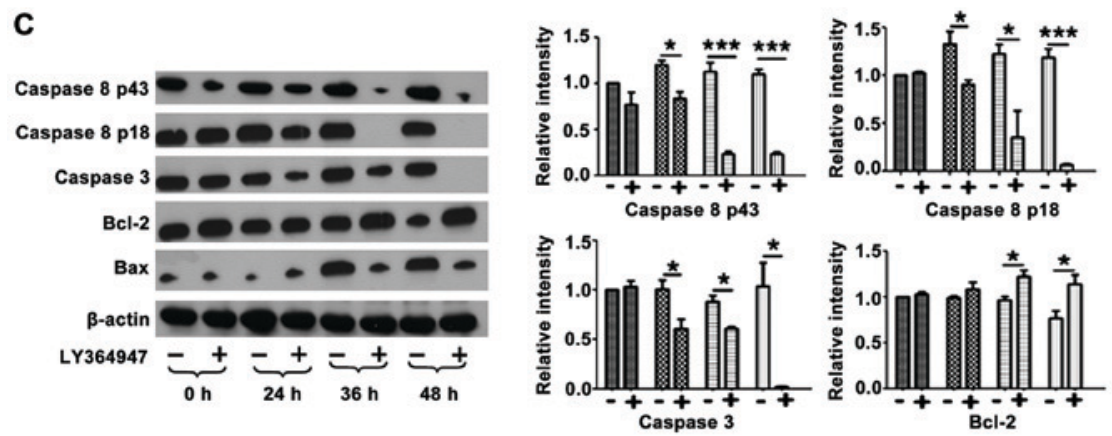

Aspirin (3.5 micromolar)

Control

$\square_{\text {LY364947 }}^{\text {Assirin (3.5 micromolar)+ }}$

Control

Aspirin (3.5 micromolar)

Aspirin (3.5 micromolar)+

LY364947

Figure 3. LY364947 partially rescues the effect of aspirin on CT26 cell viability. (A) Viability of CT26 cells following treatment with 3 or $3.5 \mu \mathrm{M}$ aspirin and/or $1 \mu \mathrm{M} \mathrm{LY} 364947$. (B) Flow cytometry results and percentage of early and late apoptotic cells following treatment with $3.5 \mu \mathrm{M}$ aspirin and/or $1 \mu \mathrm{M} \mathrm{LY} 364947$ for the indicated time points. (C) Representative western blot analysis and quantification of protein levels of caspase 8, caspase 3, Bcl-2 and Bax following treatment with $3.5 \mu \mathrm{M}$ aspirin and/or $1 \mu \mathrm{M} \mathrm{LY} 364947$ for the indicated time points. The control group was $0 \mathrm{~h}$, which received no treatment. ${ }^{*} \mathrm{P}<0.05,{ }^{* *} \mathrm{P}<0.03$, ${ }^{* * * *} \mathrm{P}<0.01,{ }^{* * * * *} \mathrm{P}<0.001$. FITC, fluorescein isothiocyanate; PI, propidium iodide; OD, optical density; Bcl-2, B-cell lymphoma 2; Bax, Bcl-associated X protein.

necrosis factor-related apoptosis-inducing ligand, and may act synergistically with the inhibition of COX-2-dependent prostaglandin formation $(38,39)$. The two pathways work together and result in the apoptosis of tumor cells.
The life span of cancer cells within a living system is significantly affected by the rate of apoptosis (40), which has been recognized as an important physiological event in the pharmacology of anticancer agents $(41,42)$. The regulation 
of apoptosis has become an area of extensive analysis in cancer studies (43). Aspirin may affect apoptosis through prostaglandin-dependent or prostaglandin-independent pathways (44). In prostaglandin-dependent pathways, the inhibition of COX, particularly COX-2, is the primary mechan is minvolved in CRC suppression by aspirin (8-11). COX-2 is undetectable in the normal epithelium, but is detectable in $>80 \%$ of patients with CRC and is associated with larger tumor size and deeper tissue invasion (45). However, not all human colonic cancer cells express COX-2 and produce prostaglandins $(46,47)$. Several studies have demonstrated that high aspirin dosages may also affect apoptosis and cell proliferation in CRC via COX-2 independent pathways $(37,48,49)$. These mechanisms include: i) $\mathrm{Wnt} / \beta$-catenin pathway inhibition (50); ii) interleukin-6/signal transducer and activator of transcription 3 signaling pathway (51); iii) the downregulation of special protein(Sp)1, Sp3, Sp4 and numerous Sp-regulated gene products (52); iv) the regulation of various targets, including 15-lipoxygenase-1 (53) or the pro-apoptoticproteinprotease-activated receptor 4 (54); v) activation of $\mathrm{p} 38 /$ mitogen-activated protein kinase (MAPK) (55), caspases (56) or the ceramide pathway (57); vi) the release of mitochondrial cytochrome $c$ (58); vii) the induction of autophagy in colorectal cancer cells (59); viii) inhibiting the activation of nuclear factor- $\kappa \mathrm{B}(60)$, which has been implicated in cellular adhesion (61), and the promotion of metastasis (62).

In addition, aspirin may be administered for cancer treatment due to its indirect function in reducing drug resistance or enhancing the antitumor effects of other drugs (63). Furthermore, aspirin may suppress the pro-invasion and pro-metastasis effects of sorafenib in hepatocellular carcinoma (HCC) through the upregulation of oxidoreductase HTATIP2, which is potentially mediated by the inhibition of COX2 expression, and it may improve the efficacy of sorafenib (63). An additional study revealed that aspirin enhanced doxorubicin-induced apoptosis and reduced tumor growth in human HCC cells in vitro and in vivo (64).

TGF- $\beta 1$ is a versatile cytokine that is involved in cell-cycle control, the regulation of early development, differentiation, extracellular matrix formation, hematopoiesis, angiogenesis, chemotaxis and immune functions (15). Proliferation of a number of epithelial cell types may be inhibited by TGF- $\beta 1$, including intestinal epithelial cells, whereas the growth of mesenchymal cells is stimulated (65). TGF- $\beta 1$ is also an inhibitor of tumor growth that is capable of inducing apoptosis in various types of cancer cells; however, the reaction of diverse malignant cells to TGF- $\beta 1$ is different: During the process of cancer development, certain transformed cells become partly or completely resistant to TGF- $\beta 1$ growth inhibition (12), resulting in the uncontrolled proliferation of the cells (52). However, specific cancer cells remain sensitive to TGF- $\beta 1$, which may lead to proliferation inhibition and the induction of apoptosis in these cells (16). A number of transgenic mouse studies have also provided evidence for the hypothesis that one of the roles of the TGF- $\beta 1$ signaling pathway is to provide protection against malignant transformation $(17,18)$. Transgenic mice that produce a constitutively active form of TGF- $\beta 1$ are resistant to DMBA-induced mammary tumor formation (17). Patients with breast cancer and high expression levels of TGF- $\beta 1$ appear to exhibit longer disease-free intervals and a significantly improved probability of survival (66).

In summary, the present study has suggested a novel pathway for aspirin-induced CRC cell apoptosis. More specifically, aspirin induces CRC cell apoptosis by elevating the secretion of TGF- $\beta 1$ by those cells, and the increased levels of TGF- $\beta 1$ in turn lead to apoptosis and proliferation inhibition in the CRC cells. There are certain limitations associated with the present study. Firstly, concentrations of 3 and $3.5 \mu \mathrm{M}$ aspirin were used to treat the CT26 cells, as lower doses of aspirin were unable to induce apoptosis and proliferation inhibition following treatment for $48 \mathrm{~h}$; this concentration of aspirin induced a secretion of $\sim 1,000 \mathrm{pg}$ TGF- $\beta 1$ by $1 \times 10^{5}$ CT2 6 cells. However, $100 \mathrm{ng} / \mathrm{ml}$ TGF- $\beta 1$, a20-fold lower concentration compared with the amount induced by aspirin, was used to examine whether TGF- $\beta 1$ is capable of inducing apoptosis and proliferation inhibition in CT26 cells. It was not possible to test higher concentrations of TGF- $\beta 1$ induced by aspirin due to the high cost of commercial TGF- $\beta 1$ protein. However, if a significantly lower dose of TGF- $\beta 1$ was able to induce apoptosis and proliferation inhibition in CT26 cells, it is reasonable to predict that higher concentrations would elicita similar effect. Alterations in the expression levels of various apoptotic proteins in CT26 cells following treatment with $3.5 \mu \mathrm{M}$ aspirin were observed, but these changes did not appear in the cells following treatment with $100 \mathrm{ng} / \mathrm{ml}$ TGF- $\beta 1$. Whether $100 \mathrm{ng} / \mathrm{ml}$ TGF- $\beta 1$ is able to induce apoptosis in CT26 cells without affecting the caspase proteins remains to be determined. Furthermore, caspase-independent pathways, such as the AIF-endonuclease G-Omi/HtrA pathway, may also induce apoptosis in these cells (67). Whether this pathway was involved at the relatively low concentrations of TGF- $\beta 1$-induced apoptosis in the present study, and whether higher and lower concentrations of TGF- $\beta 1$ may induce apoptosis via alternate pathways remains to be elucidated, and additional studies are required. Secondly, the present study only focused on a small number of apoptotic proteins, including the caspase 8 fragments p43 and p18, caspase $3, \mathrm{Bcl}-2$ and Bax. An association has previously been demonstrated between TGF- $\beta 1$ and the well-known extracellular signal-regulated kinase (ERK)1/2-MAPK signaling pathway (68). Whether aspirin exhibits any significant effects on this pathway has yet to be determined and additional studies are required.

\section{Acknowledgements}

The present study was funded by The National Natural Science Foundation of China (grant no. 81201787).

\section{References}

1. Ugurlucan M, Caglar IM, Caglar FN, Ziyade S, Karatepe O, Yildiz Y,Zencirci E, Ugurlucan FG, Arslan AH, Korkmaz S, et al: Aspirin: From a historical perspective. Recent Pat Cardiovasc Drug Discov 7: 71-76, 2012.

2. Vane JR, Flower RJ and Botting RM: History of aspirin and its mechanism of action. Stroke 21(12 Suppl): IV12-IV23, 1990.

3. Wang S, Liu Z, Wang L and Zhang X: NF-kappaB signaling pathway, inflammation and colorectal cancer. Cell Mol Immunol 6: 327-334, 2009. 
4. Menter DG and Dubois RN: Prostaglandins in cancer cell adhesion, migration, and invasion. Int J Cell Biol 2012: 723419, 2012.

5. Kanaoka S, Yoshida K, Miura N, Sugimura H and Kajimura M: Potential usefulness of detecting cyclooxygenase 2 messenger RNA in feces for colorectal cancer screening. Gastroenterology 127: 422-427, 2004.

6. Fenwick SW, Toogood GJ, Lodge JP and Hull MA: The effect of the selective cyclooxygenase-2 inhibitor rofecoxib on human colorectal cancerliver metastases. Gastroenterology 125: 716-729, 2003.

7. Krishnan K, Ruffin MT, Normolle D, Shureiqi I, Burney K, Bailey J, Peters-Golden M, Rock CL, Boland CR and Brenner DE: Colonic mucosal prostaglandin E2 and cyclooxygenase expression before and after low aspirin doses in subjects at high risk or at normal risk for colorectal cancer. Cancer Epidemiol Biomarkers Prev 10: 447-453, 2001.

8. DerynckR andZhang YE:Smad-dependentandSmad-independent pathways in TGF-beta family signaling. Nature 425: 577-584, 2003.

9. Moon CM, Kwon JH, Kim JS, Oh SH, Jin Lee K, Park JJ, Pil Hong S, Cheon JH, Kim TI and Kim WH: Nonsteroidal anti-inflammatory drugs suppress cancer stem cells via inhibiting PTGS2 (cyclooxygenase 2) and NOTCH/HES1 and activating PPARG in colorectal cancer. Int J Cancer 134: 519-529, 2014

10. Vaish V, Tanwar L and Sanyal SN: The role of NF- $\kappa$ B and PPAR $\gamma$ in experimentally induced colorectal cancer and chemoprevention by cyclooxygenase-2 inhibitors. Tumour Biol 31: 427-436, 2010.

11. Ishizaki T, Katsumata K, Tsuchida A, Wada T, Mori Y, Hisada M, Kawakita $\mathrm{H}$ and Aoki T: Etodolac, a selective cyclooxygenase-2 inhibitor, inhibits liver metastasis of colorectal cancercells via the suppression of MMP-9 activity. Int J Mol Med 17: 357-362, 2006

12. Shureiqi I, Chen D, Lotan R, Yang P, Newman RA, Fischer SM and Lippman SM: 15-Lipoxygenase-1 mediates nonsteroidalanti-inflammatory drug-induced apoptosis independently of cyclooxygenase-2 in colon cancer cells. Cancer Res 60 6846-6850, 2000

13. Zhou X, Huang SY, Feng JX, Gao YY, Zhao L, Lu J, Huang BQ and Zhang Y: SOX7 is involved in aspirin-mediated growth inhibition of human colorectal cancer cells. World J Gastroenterol 17: 4922-4927, 2011.

14. Blobe GC, Schiemann WP and Lodish HF: Role of transforming growth factor beta in human disease. N Engl J Med 342: $1350-1358,2000$

15. Govinden R and Bhoola KD: Genealogy, expression, and cellular function of transforming growth factor-beta. Pharmacol Ther 98 : 257-265, 2003.

16. Sánchez-Capelo A: Dual role for TGF-betal in apoptosis Cytokine Growth Factor Rev 16: 15-34, 2005.

17. Pierce DF Jr, Gorska AE, Chytil A, Meise KS, Page DL, Coffey RJ Jr and Moses HL: Mammary tumor suppression by transforming growth factor beta 1 transgene expression. Proc Natl Acad Sci USA 92: 4254-4258, 1995.

18. Chen L, Lu X, Zeng T, Chen Y, Chen Q, Wu W, Yan X, Cai H, Zhang Z, Shao Q and Qin W: Enhancement of DEN-induced liver tumourigenesis in hepatocyte-specific Lass2-knockout mice coincident with upregulation of the TGF- $\beta 1-$ Smad4-PAI- 1 axis. Oncol Rep 31: 885-893, 2014.

19. Elmore S: Apoptosis: A review of programmed death. Toxicol Pathol 35: 495-516, 2007.

19. Wang Y, Jiang M, Li Z, Wang J, Du C, Yanyang L, Yu Y, Wang X, Zhang N, Zhao M, et al: Hypoxia and TGF- $\beta 1$ lead to endostatin resistance by cooperatively increasing cancer stem cellsin A549 transplantation tumors. Cell Biosci 5: 72, 2015.

20. Yue W, Zheng X, Lin Y, Yang CS, Xu Q, Carpizo D, Huang H, DiPaola RS and Tan XL: Metformin combined with aspirin significantly inhibit pancreatic cancer cell growth in vitro and in vivo by suppressing anti-apoptotic proteins Mcl-1 and Bcl-2. Oncotarget 6: 21208-21224, 2015.

21. Koseki T, Yamato K, Krajewski S, Reed JC, Tsujimoto Y and Nishihara T: Activin A-induced apoptosis is suppressed by BCL-2. FEBS Lett 376: 247-250, 1995.

22. Saltzman A, Munro R, Searfoss G, Franks C, Jaye M and Ivashchenko Y: Transforming growth factor-beta-mediated apoptosis in the Ramos B-lymphoma cell line is accompanied by caspase activation and Bcl-XL downregulation. Exp Cell Res 242: 244-254, 1998.

23. Fukuchi Y, Kizaki M, Yamato K, Kawamura C, Umezawa A, Hata Ji, Nishihara T and Ikeda Y: Mcl-1, an early-induction molecule, modulates activin A-induced apoptosis and differentiation of CML cells. Oncogene 20: 704-713, 2001.
24. Chen RH and Chang TY: Involvement of caspase family proteases in transforming growth factor-beta-induced apoptosis. Cell Growth Differ 8: 821-827, 1997.

25. Boatright KM and Salvesen GS: Mechanisms of caspase activation. Curr Opin Cell Biol 15: 725-731, 2003

26. Riedl SJ and Shi Y: Molecular mechanisms of caspase regulation during apoptosis. Nat Rev Mol Cell Biol 5: 897-907, 2004

27. Thornberry NA and Lazebnik Y: Caspases: Enemies within. Science 281: 1312-1316, 1998.

28. Alnemri ES: Mammalian cell death proteases: A family of highly conserved aspartate specific cysteine proteases. J Cell Biochem 64: 33-42, 1997.

29. Han BH, DeMattos RB, Dugan LL, Kim-Han JS, Brendza RP Fryer JD, Kierson M, Cirrito J, Quick K, Harmony JA, et al: Clusterin contributes to caspase-3-independent brain injury following neonatal hypoxia-ischemia. Nat Med 7: 338-343, 2001

30. Thompson CB: Apoptosis in the pathogenesis and treatment of disease. Science 267: 1456-1462, 1995.

31. Kuhn P and Sarkar DK: Ethanol induces apoptotic death of b-Endorphin neurons in the rat Hypothalamus by a TGF-beta 1-dependent mechanism. Alcohol Clin Exp Res 32: 706-714, 2008.

32. Jänne PA and Mayer RJ: Chemoprevention of colorectal cancer. N Engl J Med 342: 1960-1968, 2000.

33. Algra AM and Rothwell PM: Effects of regular aspirin on long-term cancer incidence and metastasis: A systematic comparison of evidence from observational studies versus randomised trials. Lancet Oncol 13: 518-527, 2012.

34. Rothwell PM, Wilson CE, Elwin M, Norrving B, Algra A, Warlow CP and Meade TW: Long-term effect of aspirin on colorectal cancer incidence and mortality: 20-year follow-up of five randomized trials. Lancet 376: 1741-1750, 2010

35. Patrono C and Rocca B: Aspirin: promise and resistance in the new millennium. Arterioscler Thromb Vasc Biol 28(Suppl): s25-s32, 2008.

36. Lai MY, Huang JA, Liang ZH, Jiang HX and Tang GD: Mechanisms underlying aspirin-mediated growth inhibition and apoptosis induction of cyclooxygenase-2 negative colon cancer cell line SW480. World J Gastroenterol 14: 4227-4233, 2008.

37. Bos CL, Kodach LL, van den Brink GR, Diks SH, van Santen MM, Richel DJ, Peppelenbosch MP and Hardwick JC: Effect of aspirin on the Wnt/beta-catenin pathway is mediated via protein phosphatase 2A. Oncogene 25: 6447-6456, 2006.

38. Martin S, Phillips DC, Szekely-Szucs K, Elghazi L, Desmots F and Houghton JA: Cyclooxygenase-2 inhibition sensitizes human colon carcinoma cells to TRAIL-induced apoptosis through clustering of DR5 and concentrating death-inducing signaling complex components into ceramide-enriched caveolae. Cancer Res 65: 11447-11458, 2005.

39. Kim KM, Song JJ, An JY, Kwon YT and Lee YJ: Pretreatment of acetylsalicylic acid promotes tumor necrosis factor-related apoptosis-inducing ligand-induced apoptosis by down-regulating BCL-2 gene expression. J Biol Chem 280: 41047-41056, 2005.

40. Johnstone RW, Ruefli AA and Lowe SW: Apoptosis: A link between cancer genetics and chemotherapy. Cell 108: 153-164, 2002.

41. Chinnaiyan AM and Dixit VM: The cell-death machine. Curr Biol 6: 555-562, 1996.

42. Kasibhatla S and Tseng B: Why target apoptosis in cancer treatment? Mol Cancer Ther 2: 573-580, 2003.

43. Makin G: Targeting apoptosis in cancer chemotherapy. Expert Opin Ther Targets 6: 73-84, 2002.

44. Marx J. Cancer research. Anti-inflammatories inhibit cancer growth-but how? Science 291: 581-582, 2001

45. Fujita T, Matsui M, Takaku K, Uetake H, Ichikawa W, Taketo MM and Sugihara K: Size- and invasion-dependent increase in cyclooxygenase 2 levels in human colorectal carcinomas. Cancer Res 58: 4823-4826, 1998.

46. Marnett LJ: Aspirin and the potential role of prostaglandins in colon cancer. Cancer Res 52: 5575-5589, 1992.

47. Hanif R, Pittas A, Feng Y, Koutsos MI, Qiao L, Staiano-Coico L, Shiff SI and Rigas B: Effects of nonsteroidal anti-inflammatory drugs onproliferation and on induction of apoptosis in colon cancer cells by a prostaglandin-independent pathway. Biochem Pharmacol 52: 237-245, 1996

48. Thun MJ, Jacobs EJ and Patrono C: The role of aspirin in cancer prevention. Nat Rev Clin Oncol 9: 259-267, 2012.

49. Sun Y, Chen J and Rigas B: Chemopreventive agents induce oxidative stress in cancer cells leading to COX-2 overexpression and COX-2-independent cell death. Carcinogenesis 30: 93-100, 2009. 
50. Shtivelband MI, Juneja HS, Lee S and Wu KK: Aspirin and salicylate inhibit colon cancer medium- and VEGF-induced endothelial tube formation: Correlation with suppression of cyclooxygenase-2 expression. J ThrombHaemost 1: 2225-2233, 2003.

51. Tian Y, Ye Y, Gao W, Chen H, Song T, Wang D, Mao X and Ren C: Aspirin promotes apoptosis in a murine model of colorectal cancer by mechanisms involving downregulation of IL-6-STAT3 signaling pathway. Int J Colorectal Dis 26: 13-22, 2011.

52. Pathi S, Jutooru I, Chadalapaka G, Nair V, Lee SO and Safe S: Aspirin inhibits colon cancer cell and tumor growth and downregulates specificity protein (Sp) transcription factors. PLoS One 7: e48208, 2012.

53. Shureiqi I, Xu X, Chen D, Lotan R, Morris JS, Fischer SM and Lippman SM: Nonsteroidal anti-inflammatory drugs induce apoptosis in esophageal cancer cells by restoring 15-lipoxygenase-1 expression. Cancer Res 61: 4879-4884, 2001.

54. Zhang Z and DuBois RN: Par-4, a proapoptoticgene, is regulated by NSAIDs in human colon carcinoma cells. Gastroenterol 118: 1012-1017, 2000.

55. Bellosillo B, Piqué M, Barragán M, Castaño E, Villamor N, Colomer D, Montserrat E, Pons G and Gil J: Aspirin and salicylate induce apoptosis and activation of caspases in B-cell chronic lymphocytic leukaemia cells. Blood 92: 1406-1414, 1998.

56. Schwenger P, Bellosta P, Vietor I, Basilico C, Skolnik Y and Vilcek J: Sodium salicylate induces apoptosis via p38 mitogen activated protein kinase but inhibits tumour necrosis factor-induced c-Jun N-terminal kinase/stress-activated protein kinase activation. Proc Natl Acad Sci USA 94: 2869-2873, 1997.

57. Chan TA, Morin PJ, Vogelstein B and Kinzler KW: Mechanisms underlying non-steroidal anti-inflammatory drug-mediated apoptosis. Proc Natl Acad Sci USA 95: 681-686, 1998.

58. Zimmermann KC, Waterhouse NJ, Goldstein JC, Schuler M and Green DR: Aspirin induces apoptosis through release of cytochrome c from mitochondria. Neoplasia 2: 505-513, 2000.

59. Din FV, Valanciute A, Houde VP, Zibrova D, Green KA, Sakamoto K, Alessi DR and Dunlop G: Aspirin inhibits mTOR signaling, activates AMP-activated protein kinase, and induces autophagy in colorectal cancer cells. Gastroenterology 142: 1504-1515.e3, 2012
60. Takada Y, Bhardwaj A, Potdar P and Aggarwal BB: Nonsteroidal anti-inflammatory agents differ in their ability to suppress NF-kappaB activation, inhibition of expression of cyclooxygenase-2 and cyclin D1, and abrogation of tumor cell proliferation. Oncogene 23: 9247-9258, 2004.

61. Tozawa K, Sakurada S, Kohri K and Okamoto T: Effects of anti-nuclear factor kappa $\mathrm{B}$ reagents in blocking adhesion of human cancer cells to vascular endothelial cells. Cancer Res 55: 4162-4167, 1995

62. Fujioka S, Sclabas GM, Schmidt C, Frederick WA, Dong QG, Abbruzzese JL, Evans DB, Baker C and Chiao PJ: Function of nuclear factor kappaB in pancreatic cancer metastasis. Clin Cancer Res 9: 346-354, 2003.

63. Lu L, Sun HC, Zhang W, Chai ZT, Zhu XD, Kong LQ, Wang WQ, Zhang KZ, Zhang YY, Zhang QB, et al: Aspirin minimized the pro-metastasis effect of sorafenib and improved survival by up-regulating HTATIP2 in hepatocellular carcinoma. PLoS One 8: e65023, 2013.

64. Hossain MA, Kim DH, Jang JY, Kang YJ, Yoon JH, Moon JO, Chung HY, Kim GY, Choi YH, Copple BL and Kim ND: Aspirin enhances doxorubicin-induced apoptosis and reduces tumor growth in human hepatocellular carcinoma cells in vitro and in vivo. Int J Oncol 40: 1636-1642, 2012.

65. Smith RD: Evidence for autocrine growth inhibition of rat intestinal epithelial (RIE-1) cells by transforming growth factor type-beta. Biochem Mol Biol Int 35: 1315-1321, 1995.

66. Murray PA, Barrett-Lee P, Travers M, Luqmani Y, Powles T and Coombes RC: The prognostic significance of transforming grow th factors in human breast cancer. Br J Cancer 67: 1408-1412, 1993.

67. Sun Y, Gao W, Zhao Y, Cao W, Liu Z, Cui G, Tong L, Lei F and Tang B: Visualization and inhibition of mitochondria-nuclear translocation of apoptosis inducing factor by a graphene oxide-DNA nanosensor. Anal Chem 89: 4642-4647, 2017.

68. Oussaief L, Hippocrate A, Ramirez V, Rampanou A, Zhang W Meyers D, Cole P, Khelifa R and Joab I: Phosphatidylinositol 3-kinase/Akt pathway targets acetylation of Smad3 through Smad3/CREB-binding protein interaction: Contribution to transforming growthfactorbeta1-inducedEpstein-Barrvirusreactivation. J Biol Chem 284: 23912-23924, 2009. 